\title{
Effect of microbes, npk fertilizer and cow dung on the biodegradation of polycyclic aromatic hydrocarbons from abattoir wastes in Nigeria
}

\author{
D. N. Ogbonna ${ }^{1, *}$, T. J. K. Ideriah ${ }^{2, *}$, M. I. Nwachukwu ${ }^{3}$ \\ ${ }^{1}$ Department of Applied and Environmental Biology, Rivers State University of Science and Technology, Nkpolu-Oroworukwo, Port \\ Harcourt, Nigeria \\ ${ }^{2}$ Institute of Pollution Studies, Rivers State University of Science and Technology, Nkpolu-Oroworukwo, Port Harcourt, Nigeria \\ ${ }^{3}$ Department of Microbiology, Imo State University, Owerri
}

Email adress:

dnogbonna@yahoo.com (D. N. Ogbonna), itubonimi@yahoo.com (T. J. K. Ideriah)

\section{To cite this article:}

D. N. Ogbonna, T. J. K. Ideriah, M. I. Nwachukwu. Effect of Microbes, Npk Fertilizer and Cow Dung on the Biodegradation of Polycyclic Aromatic Hydrocarbons from Abattoir Wastes in Nigeria. International Journal of Environmental Monitoring and Analysis, Vol. 1, No. 1, 2013, pp. 1-14. doi: 10.11648/j.ijema.20130101.11

\begin{abstract}
The biodegradation of polycyclic aromatic hydrocarbons by associated microorganisms were studied. Soil and waste water samples were collected from four abattoirs located at Egbu and Ogbe in Imo state, Trans-Amadi and Ahoada in Rivers State. Likewise, surface water and sediment samples from Otamiri River and Oginigba Creek adjoined to Egbu and Trans-Amadi abattoirs, respectively were collected using standard methods. The ability of hydrocarbon utilizing bacteria and fungi to biodegrade polycyclic aromatic hydrocarbons (PAHs) was carried out by growing the isolates in a mineral salt broth amended with PAHs and nutrients (NPK fertilizer and cow dung). Levels of polycyclic aromatic hydrocarbons (PAHs) left after incubation were determined using Gas chromatographic method. Results showed that soil samples from various abattoirs had high concentrations of PAHs ranging from $0.176 \mathrm{mg} / \mathrm{kg}$ at Ahoada abattoir to $2.44 \mathrm{mg} / \mathrm{kg}$ at Egbu abattoir. In a 21-day biodegradation test, there was a drop in the initial concentration of PAHs used as control from $0.03 \mathrm{mg} / 1$ to 0.024 $\mathrm{mg} / \mathrm{l}$. There was loss of low molecular weight PAHs than the high molecular weight components. It is evident from the study that both mixed cultures of bacteria and fungi can biodegrade polycyclic aromatic hydrocarbons. Results from this study have shown that abattoir wastes have high pollution strength and thus should be treated before being discharged into the environment. Of note is the fact that the microorganisms isolated from the abattoirs are potential agents of remedying environments impacted by polycyclic aromatic hydrocarbons (PAHs).
\end{abstract}

Keywords: Polycyclic Aromatic Hydrocarbons, Abattoir, Biodegradation, Microorganisms, NPK, Cow Dung

\section{Introduction}

Polycyclic aromatic hydrocarbons (PAHs) are ubiquitous environmental pollutants generated from both natural and anthropogenic processes and pose a serious concern to the health of aquatic life and humans through bioaccumulation[1],[2],[3],[4],[5],[6]. Polycyclic aromatic hydrocarbons (PAHs) have been recognized as a heterogeneous group of persistent contaminants, due to their toxic, carcinogenic and mutagenic properties and high recalcitrance to different types of degradation[7],[8]. PAHs are hydrophobic and readily adsorbed onto particulate matter and thus, coastal and marine sediments become the ultimate sinks for such compounds[1],[9],[10]. PAHs cause major impacts owing to their carcinogenic nature in marine organisms such as benthic, demersal and pelagic fishes, crustaceans and shellfish[11].

The decontamination of PAH-polluted sites is of major importance because many PAH compounds are either known or suspected carcinogens and mutagens[12]. Most low molecular weight PAHs are biodegradable in the presence of suitable microbial populations and a number of bioremediation programs have had some success in the decontamination of PAH - contaminated sites[13]. However, the extent and rate of PAH biodegradation are restricted by the limited bioavailability of these compounds, which is due to their low aqueous solubilities and strong adsorptive capacity to soil and sediments[14]. In addition to these are lack of nutrients and scarcity of PAH biodegrading microorganisms[15]. Coupled with this, they are thermodynami- 
cally stable since they are derivatives of the benzene ring with large negative resonance energies[13].Though low molecular weight PAHs are biodegradable, high - ring number PAHs are difficult to biodegrade[13]. This is because the environmental fate of a PAH particle is dependent in part on both its molecular size i.e. the number of aromatic rings and pattern of ring linkages. Generally, an increase in the size and angularity of a PAH molecule results in a concomitant increase in hydrophobicity and electrochemical stability[16].

Organic wastes, such as animal manure, straw, compost and sewage sludge, have often been used to improve soil quality, by altering the physical properties (soil aggregation),ameliorating soil organic matter (SOM) quantity, increasing nutrient availability, and other soil functions[17],[18],[19]. Several studies have focused on improved organic pollutant (PAHs, PCB or PCP) biodegradation by waste organic material amendments in artificially contaminated soil[20],[21],[22],[23],[24],[25].

Little is known about the biodegradation of mixtures of PAHs especially the effect of one PAH component on the biodegradation of another[13]. However, there has been increased interest in developing and understanding of microbial degradation process when PAHs are present in complex mixtures. A mixture of contaminants in a bioremediation system may result in inhibition, co-metabolism, augmentation or no effect at all[1]. For instance, both inhibition and co-metabolism have been observed in the degradation of a simple mixture of phenanthrene and fluorantene by a Pseudomonas sp.[26].

Previous studies of PAH degradation by mixed and pure cultures presented evidence that there are interactions between PAHs in mixtures that influence biodegradation, for example, exposure of marine sediments to one PAH was observed to enhance degradation of other subsequently added PAHs[27]. Mixed microbial populations from marine waters sequentially mineralized naphthalene, phenanthrene and anthracene suggesting preferential utilization of substrates by a general PAH - degrading population[27]. Sequential removal of PAHs has also been demonstrated in batch incubations where recalcitrant PAHs were removed truly after more labile PAHs were degraded[28]. A report[29] showed that higher - molecular weight PAHs were more resistant to biotransformation when present as pure compounds in soil than when present in complex waste mixtures in soil, whereas lower molecular weight PAHs were transformed more rapidly as pure compounds. Although substantial evidence exists that PAH - degrading bacteria often metabolize a range of PAH substrates[30], little is known about the specificity of the enzymes involved in PAH degradation. It has been demonstrated that cis-naphthalene dihydrodiol dehydrogenase oxidizes cis-dihydrodiols of other polycyclic aromatic hydrocarbons[31]. The same report[31] further stated that NAH7 and NAH7-like plasmids, which encode genes responsible for naphthalene metabolism, can also mediate the mineralization of phenanthrene and anthracene. Metabo- lites from anthracene and phenanthrene catabolism by NAH7-like plasmid encoded enzymes were identified as 2-hydroxyl-3-naphthoic acid and 1-hydroxyl-2naphthoic acid respectively[32], which are metabolites of previously described bacteria degradation pathways. Recently[33] presented molecular evidence that dibenzothiophene, naphthalene and phenanthrene are metabolized by a single set of upper-pathway enzymes in a soil pseudomonad.

Hydrocarbon biodegradation in terrestrial ecosystems may be limited by the available water for the microbial growth and metabolism[34]. In a study[35] of oil sludge degradation in soil, reported optimal rates of biodegradation at 30 to $90 \%$ water saturation. The failure according to[35] to observe inhibition of degradation at the lower values was ascribed to a hydrocarbon - mediated reduction in the water - holding capacity of the soil.

\section{Materials and Methods}

\subsection{Study Area}

The study was carried out in abattoirs located at Ogbe and Egbu in Imo State, Trans-Amadi in Port Harcourt and Ahoada both in Rivers State. Ogbe lies on longitude $05^{\circ}$ $31.965^{\prime}-05^{\circ} 32.890^{\prime} \mathrm{N}$ and latitude $007^{\circ} 15.695^{\prime}-007^{\circ}$ $18.010^{\prime} \mathrm{E}$, while Egbu lies within longitude $05^{\circ} 28.432^{\prime}-05^{\circ}$ $29.802^{\prime} \mathrm{N}$ and latitude $007^{\circ} 03.200^{\prime}-007^{\circ} 04.215^{\prime} \mathrm{E}$. These areas have a tropical climate. The average relative humidity is about $80 \%$. The inhabitants of the areas are mainly farmers, civil servants, petty traders and casual workers.

Port Harcourt is located on longitude $4^{\circ} 48.442^{\prime}-4^{\circ}$ $49.444^{\prime} \mathrm{N}$ and latitude $007^{\circ} 02.303^{\prime}-007^{\circ} 03.545^{\prime} \mathrm{E}$. The climate of Port Harcourt falls within the sub equatorial climate belt. Temperature and humidity are high throughout the year. The area is marked by two distinct seasons, the wet season and the dry season, with $70 \%$ of the annual rain fall between April and August, while 22\% is spread in the three months of September to November. However, the driest months are from December to March. Ahoada is located on longitude $4^{\circ} 28.222^{\prime}-4^{\circ} 50.111^{\prime} \mathrm{N}$ and latitude $006^{\circ}$ $43.122^{\prime}-007^{\circ} 04.225^{\prime} \mathrm{E}$. The inhabitants of the area are mainly civil servants, traders and farmers.

\subsection{Identification of Sampling Points}

A total of thirty six (36) sampling points were selected for the study (Table 1).

\subsection{Collection of Samples}

\subsubsection{Chemicals and Reagents}

Crude oil (Bonny light) was obtained from Shell Petroleum Development Company Port Harcourt, Nigeria. Polyaromatic hydrocarbons were purchased from Sigma Chemical Company (St Louis, MO). Other solvents and chemicals were obtained in analytical grade from BDH laboratory supplies (Poole, England). Bacteriological media including potato dextrose agar, nutrient agar, nutrient 
broth, beef extract agar, MacConkey agar, Salmonella- Ltd., Hampshire, England).

Shigella agar, etc were purchased from oxoid (Uni-path

Table 1. Identification of Sampling stations and points

\begin{tabular}{|c|c|c|c|c|}
\hline Sampling Stations & Sampling Points codes & Sampling point Northing (N) & Co-ordinates Easting (E) & Types of Samples \\
\hline & A & $05^{0} 31.965^{\prime}$ & $007^{0} 16.901^{\prime}$ & Soil (Test sample) \\
\hline & B & $05^{0} 32.800^{\prime}$ & $007^{0} 15.800^{\prime}$ & Soil (Test sample) \\
\hline \multicolumn{5}{|l|}{ Ogbe Abattoir I } \\
\hline & $\mathrm{C}$ & $05^{0} 32.890^{\prime}$ & $007^{0} 15.695^{\prime}$ & Soil (Test sample) \\
\hline & D & $05^{0} 32.065^{\prime}$ & $007^{0} 17.001^{\prime}$ & Soil (Control) \\
\hline & A & $05^{0} 31.884^{\prime}$ & $007^{0} 6.964^{\prime}$ & Waste water \\
\hline & B & $05^{0} 31.665^{\prime}$ & $007^{0} 16.335^{\prime}$ & Waste water \\
\hline \multicolumn{5}{|l|}{ Ogbe Abattoir II } \\
\hline & $\mathrm{C}$ & $05^{0} 31.578^{\prime}$ & $007^{0} 16.315^{\prime}$ & Waste water \\
\hline & $\mathrm{D}$ & $05^{0} 33.000^{\prime}$ & $007^{0} 18.010^{\prime}$ & Waste water \\
\hline & A & $05^{0} 28.432^{\prime}$ & $007^{0} 03.200^{\prime}$ & Soil (Test sample) \\
\hline & B & $05^{0} 28.441^{\prime}$ & $007^{0} 03.209^{\prime}$ & Soil (Test sample) \\
\hline \multicolumn{5}{|l|}{ Egbu Abattoir I } \\
\hline & $\mathrm{C}$ & $05^{0} 28.582^{\prime}$ & $007^{0} 03.312^{\prime}$ & Soil (Test sample) \\
\hline & $\mathrm{D}$ & $05^{0} 28.559^{\prime}$ & $007^{0} 3.231^{\prime}$ & Soil (Control) \\
\hline & A & $05^{0} 29.651^{\prime}$ & $007^{0} 04.205^{\prime}$ & Waste water \\
\hline & B & $05^{0} 29.668^{\prime}$ & $007^{0} 04.215^{\prime}$ & Waste water \\
\hline \multicolumn{5}{|l|}{ Egbu Abattoir II } \\
\hline & $\mathrm{C}$ & $05^{0} 29.705^{\prime}$ & $007^{0} 04.285^{\prime}$ & Waste water \\
\hline & D & $05^{0} 29.802^{\prime}$ & $007^{0} 04.918^{\prime}$ & Waste water \\
\hline & A & $05^{0} 28.426^{\prime}$ & $007^{0} 03.179^{\prime}$ & $\begin{array}{l}\text { Surface water and } \\
\text { Sediment (Test Sample) }\end{array}$ \\
\hline & B & $05^{0} 27.423^{\prime}$ & $007^{0} 04.156^{\prime}$ & $\begin{array}{l}\text { Surface water and } \\
\text { Sediment (Control) }\end{array}$ \\
\hline & A & $04^{0} 48.886^{\prime}$ & $007^{0} 2.707^{\prime}$ & Soil (Test sample) \\
\hline & B & $04^{0} 48.782^{\prime}$ & $007^{0} 2.608^{\prime}$ & Soil (Test sample) \\
\hline \multicolumn{5}{|l|}{ Abattoir I } \\
\hline & $\mathrm{C}$ & $04^{0} 48.615^{\prime}$ & $007^{0} 2.405^{\prime}$ & Soil (Test sample) \\
\hline & D & $04^{0} 48.442^{\prime}$ & $007^{0} 2.303^{\prime}$ & Soil (Control) \\
\hline
\end{tabular}




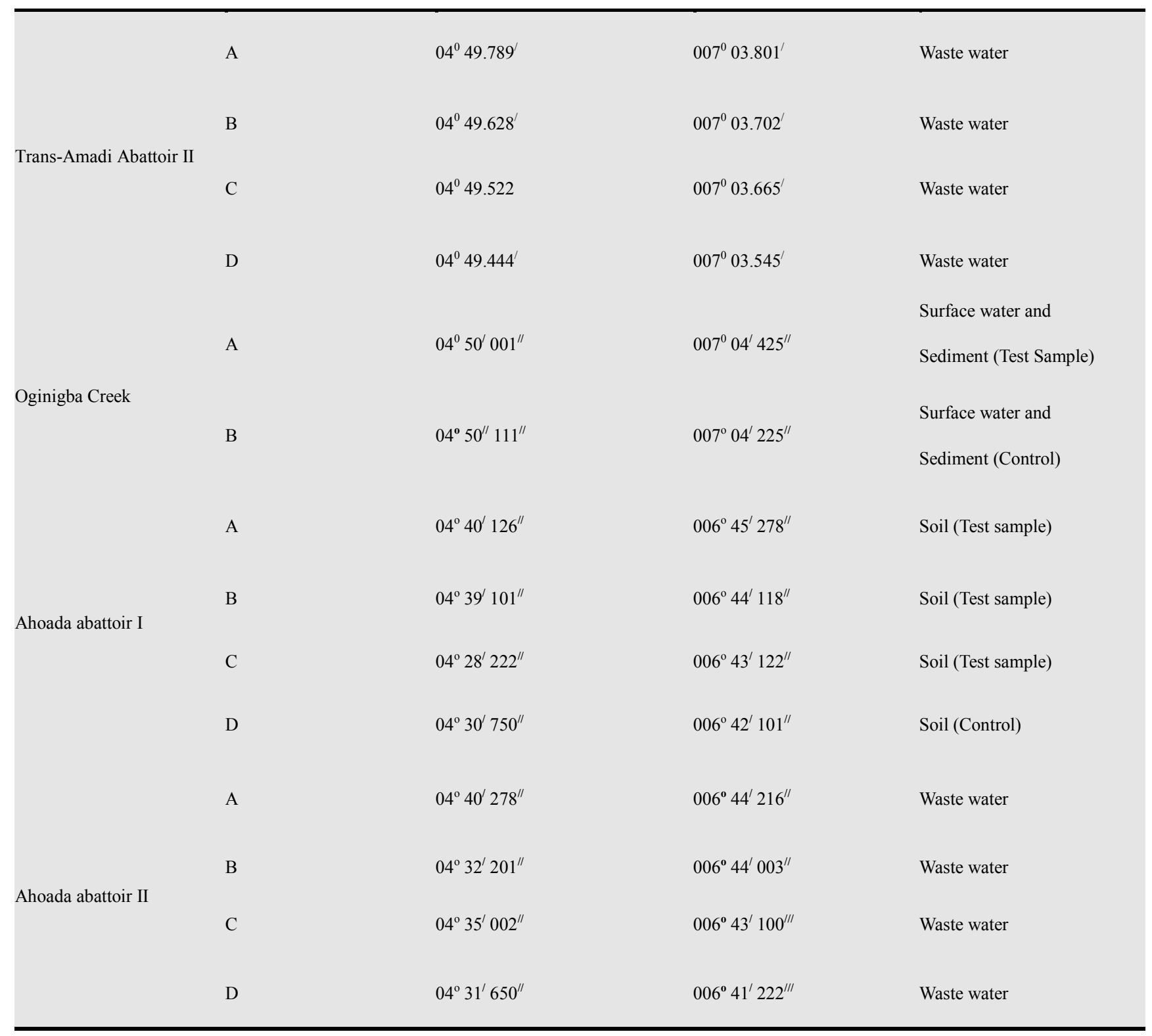

\subsubsection{Soil Samples}

Surface soil samples were collected from four different sampling points coded A, B, C and D from a depth of 0 $15 \mathrm{~cm}$ using soil auger. About 500g of bulked composite soil samples from soil samples collected from points A, B and $\mathrm{C}$ was prepared using the method of [35]. Soil sample from point $\mathrm{D}$, which is about $400 \mathrm{~m}$ from Ogbe, Egbu, Ahoada and Trans Amadi abattoirs served as control sample. The soil samples were collected into labeled polyethylene bags and transported to the laboratory in a cooler packed with ice blocks for analysis.

\subsubsection{Water Samples}

Surface water samples were collected using the method of[36]. The collection was carried out using 4.0litre plastic bottles previously sterilized with $70 \%$ alcohol 24 hours before the final collection. The bottles were rinsed 3 to 4 times with the water sample before the final collection. The water samples were collected along the course of the river at two different points coded A and B. Point A is the immediate point of discharge of the abattoir wastes into the river, Point B is about $400 \mathrm{~m}$ upstream from Point A; while sample from point A served as the test sample, that from point B served as the control sample. To collect the water sample, base of the sterilized sample bottle was held with one hand, the bottle was plunged about $30 \mathrm{~cm}$ below the water surface with the mouth of the sample bottles positioned in an opposite direction to water flow. The bottle was filled with water sample leaving a gap of about $2 \mathrm{~cm}$ and covered immediately as described by[37]. Immediately after collection, the samples were labeled and transported to the laboratory in a cooler packed with ice blocks for analysis.

\subsubsection{Sediment samples}

Sediment samples were collected from the same sampling points where surface water samples were collected using a grab sampler. The sediment sample was scooped from the grab's cup and transferred into sterile sample bottle. The sample was labeled and then transported to the 
laboratory in a cooler packed with ice blocks for analysis.

\subsubsection{Waste Water Samples}

Waste water samples were collected using the method of[38]. Sterile 2.0 litre sample bottles were used to aseptically draw part of the abattoir waste water. The samples were collected at four different points coded A, B, C and D as the waste water was running off the drainage system. About $500 \mathrm{ml}$ of the sample collected from each point were pooled together to get a composite sample. Control samples were collected from water stored in buckets used for washing meat and utensils in the abattoirs. The samples were placed in a cooler containing ice blocks and transported immediately to the laboratory for analysis.

\subsubsection{Preparation of Samples}

Sediment and soil samples were processed using the method of[38]. Ten grams of the soil sample was weighed and added to $90 \mathrm{ml}$ of sterile distilled water to get an aliquot, similarly, ten grams of the sediment sample was added to $90 \mathrm{ml}$ of sterile distilled water to get an aliquot. One milliliter of the aliquots, waste water and surface water samples were then serially diluted using the ten-fold serial dilution method as described by[39].

\subsubsection{Microbiological Analysis}

Bacterial isolates: From the dilutions of each sample $0.1 \mathrm{ml}$ aliquot was transferred aseptically into freshly prepared nutrient agar plates and spread evenly on the medium in duplicates. The inoculated plates were incubated at $37^{\circ} \mathrm{C}$ for 24 hours after which plates were examined for growth. Representative colonies of bacteria were picked from different plates after the incubation period. Pure cultures of bacteria were obtained by aseptically streaking representative colonies of different morphological types on to freshly prepared nutrient agar plates. The agar plates were incubated at $37^{\circ} \mathrm{C}$ for 24 hours. Discrete bacterial colonies, which developed on the plates, were used for subsequent characterization tests. Various tests were carried out on the bacterial isolates for possible identification. One milliliter of broth culture of each isolate was used for all the tests. Bacterial isolates were identified in accordance with the schemes of the Bergey's Manual of Determinative Bacteri$\operatorname{ology}[40]$.

Fungal isolates: Mould isolates which developed on potato dextrose agar and sabouraud's dextrose agar plates were identified using their morphological features followed by microscopic examination of their wet mounts prepared with lactophenol-cotton blue and reference made to a fungal identification atlas by[41]. Yeast isolates were also identified using their morphological characteristics, followed by the microscopic examination of their wet mount prepared with normal saline; reference was also made to a fungal identification atlas by[41]. The yeast isolates were further identified using Gram-staining, Sugar fermentation and oxidation and fermentation tests.

\subsubsection{Adaptation of Hydrocarbon Degrading Isolates}

Bacterial isolates were adapted for hydrocarbon utilization and degradation using mineral salt broth with crude oil as the sole carbon source. Incubation was at $30^{\circ} \mathrm{C}$ and aerated at 100 strokes per minute[42] for 30minutes each day for 10 days. A loopful of the adapted culture medium was transferred onto mineral salt agar that contains hydrocarbon as the only carbon source. The plates were incubated at $30^{\circ} \mathrm{C}$ for 5 days after which discrete colonies that developed were transferred onto nutrient agar plates and then incubated at $30^{\circ} \mathrm{C}$ for 24 hours after which they were stored in the refrigerator for further use.

The method described above was also used for fungi isolates though mineral salt medium used was supplemented with streptomycin $(50 \mathrm{mg} / \mathrm{l})$ to suppress bacterial growth[43]. Discrete colonies of the fungi were finally transferred onto SDA slants amended with sterile streptomycin $(50 \mathrm{mg} / \mathrm{ml})$ to suppress bacterial growth as described by[43] and then incubated at room temperature for 3-5 days after which they were stored in the refrigerator for further use.

\subsubsection{Biodegradation Experiment}

The method of[44] was adopted. The experiment was carried out in four (4) stages namely; preparation of inoculums, preparation of chemical reagents, preparation of nutrients and gas chromatographic analysis.

Preparation of inoculum: Each of the bacterial isolates which include Pseudomonas sp., Bacillis sp. and Klebsiella sp. were subcultured on a separate fresh, sterile nutrient agar medium followed by incubation at $37 \mathrm{oC}$ for 24 hours. Likewise, four fungal isolates made up of two mould isolates which include: Aspergillus sp., Penicillium sp. and two yeast isolates, which include: Saccharomyces sp. and Candida sp. were subcultured on sterile potato dextrose broth, followed by incubation at ambient temperature for 35 days.

The cells were then harvested by centrifuging at 2000rpm for 30 minutes, after which the cells were individually suspended in sterile physiological normal saline and further washed by centrifuging at 2000rpm for another 30 minutes to obtain neat cells which were suspended in sterile physiological normal saline and further diluted with sterile physiological normal saline to a low density cell suspension of 0.2 absorbance. The resultant cell suspension was diluted serially, then $0.1 \mathrm{ml}$ from $10-2$ and $10-1$ dilutions for bacteria and fungi, respectively, which served as inoculum was added to the 3 sets of experimental flasks as shown in Table 3.2 below.

\section{Composition of Biodegradation Ex- periment Cultures}

1a $97 \mathrm{ml}$ mineral salt broth $+3 \mathrm{ml} 3 \% \mathrm{PAH}+0.1 \mathrm{ml}$ mixed culture of bacteria

1b $95 \mathrm{ml}$ mineral salt broth $+3 \mathrm{ml} 3 \% \mathrm{PAH}+2 \mathrm{ml} \mathrm{NPK}$ $+0.1 \mathrm{ml}$ mixed culture of bacteria

1c $95 \mathrm{ml}$ mineral salt broth $+3 \mathrm{ml} 3 \% \mathrm{PAH}+2 \mathrm{ml} 2 \%$ cow 
dung $+0.1 \mathrm{ml}$ mixed culture of bacteria

1d $97 \mathrm{ml}$ mineral salt broth $+3 \mathrm{ml} 3 \% \mathrm{PAH}+$ No microorganism (Control)

2a $97 \mathrm{ml}$ mineral salt broth $+3 \mathrm{ml} 3 \%$ PAH $+0.1 \mathrm{ml}$ mixed culture of fungi

2b $95 \mathrm{ml}$ mineral salt broth $+3 \mathrm{ml} 3 \% \mathrm{PAH}+2 \mathrm{ml} 2 \%$ $\mathrm{NPK}+0.1 \mathrm{ml}$ mixed culture of fungi

2c $95 \mathrm{ml}$ mineral salt broth $+3 \mathrm{ml} 3 \% \mathrm{PAH}+2 \mathrm{ml} 2 \%$ cow dung $+0.1 \mathrm{ml}$ mixed culture of fungi

3a $97 \mathrm{ml}$ mineral salt broth $+3 \mathrm{ml} 3 \%$ PAH $+0.05 \mathrm{ml}$ mixed culture of bacteria $+0.05 \mathrm{ml}$ mixed culture of fungi

3b $95 \mathrm{ml}$ mineral salt broth $+3 \mathrm{ml} \mathrm{3 \%} \mathrm{PAH}+2 \mathrm{ml} 2 \%$ $\mathrm{NPK}+0.05 \mathrm{ml}$ mixed culture of bacteria $+0.05 \mathrm{ml}$ mixed culture of fungi

3c $95 \mathrm{ml}$ mineral salt broth $+3 \mathrm{ml} 3 \%$ PAH $+2 \mathrm{ml}$ cow dung $+0.05 \mathrm{ml}$ mixed culture of bacteria $+0.05 \mathrm{ml}$ mixed culture of fungi.

\subsection{Preparation of Chemical Reagent}

An ampoule of polycyclic aromatic hydrocarbon (Sigma, USA) containing $1 \mathrm{mg}$ each of naphthalene, acenaphthylene, acenaphthene, fluorene, phenanthrene, anthracene, fluoranthene, pyrene, 1, 2-Benzanthracene, chrysene, beno (b) fluoranthene, benzo (k) fluoranthene, benzo (a) pyrene, Indeno(1,2,3-C.D) pyrene, 1,2,5,6-Dibenzanthracene and 1,12-Benzoperylene was aseptically mixed with $99 \mathrm{ml}$ of sterile normal saline (diluent) making $100 \mathrm{ml}$ of stock solution and $0.01 \mathrm{mg}$ or $1 \%$ of individual polycyclic aromatic hydrocarbon constituent. From the stock solution, $3 \mathrm{ml}$ $(0.03 \mathrm{mg} / \mathrm{ml})$ representing $3 \%$ of the stock was used for the experiment.

\subsection{Preparation of Nutrients}

Extracts were stored in borosilicate glass bottles at $4^{0} \mathrm{C}$ until analysis which was usually done within 48 hours. Extracts were analyzed using a gas chromatograph (Schimadzu GC-17A gas chromatograph) (Plate 3.6) with flame ionization detector (GC-FID). The GC was equipped with an HP-1 $(30 \mathrm{~m} \times 0.25 \mu \mathrm{m})$ cross-linked methyl siloxane column connected to a split/ splitless injector. Operational conditions for analysis were: temperature: injector port, $150^{\circ} \mathrm{C}$; FID, $200^{\circ} \mathrm{C}$ and oven initially $60^{\circ} \mathrm{C}$ and programmed to reach $300^{\circ} \mathrm{C}$ at $20^{\circ} \mathrm{C}$ per min. flow rates for FID glass were; hydrogen $\left(\mathrm{H}_{2}\right), 30 \mathrm{ml} / \mathrm{min}$; air, $300 \mathrm{ml} / \mathrm{mm}$ and nitrogen $\left(\mathrm{N}_{2}\right), 30 \mathrm{ml} / \mathrm{min}$.

\section{Results}

Table 1 shows the result on the biodegradation of polycyclic aromatic hydrocarbons (PAHs) by a mixed culture of bacteria and in combination with NPK fertilizer and cow dung after 21 days. From the result, there was a significant difference (ANOVA) in the amount of PAHs remaining after 7 days, 14 days, 21 days (weekly interval). Throughout the duration, the control had the highest and slightly changed amount of PAHs. On the seventh day, PAHs + mixed culture of bacteria treatment had the least amount of PAHs. This was followed by PAHs + cow dung + mixed culture of bacteria treatment, then PAHs + mixed culture of bacteria treatment. On the fourteenth day, PAHs + mixed culture of bacteria treatment had the least quantity of PAHs remaining followed by PAHs $+\mathrm{NPK}+$ mixed culture of bacteria treatment then PAHs + cow dung + mixed culture of bacteria treatment. While on the twenty-first day, there was an absolute and total detectable loss of PAHs present in all the treatments.

Table 1. Biodegradation of polycyclic aromatic hydrocarbons (PAHs) by a mixed culture of bacteria and in combination with NPK fertilizer and cow dung.

\begin{tabular}{llll}
\hline TREATMENTS & 7 DAYS & 14 DAYS & 21 DAYS \\
\hline PAH + mixed culture of bacteria & & & \\
PAH + cow dung + mixed & $0.022^{\mathrm{b}}$ & $0.001^{\mathrm{d}}$ & $0.00^{\mathrm{b}}$ \\
culture of bacteria & $0.01^{\mathrm{c}}$ & $0.007^{\mathrm{d}}$ & $0.00^{\mathrm{b}}$ \\
PAH + NPK + mixed culture of & $0.007^{\mathrm{d}}$ & $0.003^{\mathrm{c}}$ & $0.00^{\mathrm{b}}$ \\
bacteria & $0.024^{\mathrm{a}}$ & $0.024^{\mathrm{a}}$ & $0.024^{\mathrm{a}}$ \\
PAH + no bacteria (control) & & & \\
\hline
\end{tabular}

Means in the same column with the same letter are not significantly different at $5 \%$ level of significance according to LSD test.

Table 2 shows the result on the biodegradation of polycyclic aromatic hydrocarbons (PAHs) by a mixed culture of fungi and in combination with NPK fertilizer and cow dung at a weekly interval for three weeks. At each interval (7th, 14th and 21st days), PAHs + mixed fungi culture had the highest quantity of PAHs remaining. PAHs + NPK fertilizer + mixed fungi culture had the least quantity of PAHs remaining after seven days. This treatment and PAHs + cow dung and mixed fungi culture treatment had the lowest quantity of PAHs remaining at the 14th day. On the 21st day, both treatments had a total detectable loss of PAHs. The control gives the result a significant difference with each treatment and at each interval as its value remained unchanged throughout the experiment.

Table 2. Biodegradation of polycyclic aromatic hydrocarbons (PAHs) by a mixed culture of fungi and in combination with NPK fertilizer and cow dung.

\begin{tabular}{llll}
\hline TREATMENTS & 7 DAYS & 14 DAYS & 21 DAYS \\
\hline PAH + mixed fungi culture & $0.021^{\mathrm{b}}$ & $0.014^{\mathrm{b}}$ & $0.002^{\mathrm{b}}$ \\
PAH + cow dung + mixed culture & $0.011^{\mathrm{c}}$ & $0.005^{\mathrm{c}}$ & $0.00^{\mathrm{c}}$ \\
of bacteria & $0.008^{\mathrm{d}}$ & $0.005^{\mathrm{c}}$ & $0.00^{\mathrm{c}}$ \\
PAH + NPK + mixed culture of bacteria & $0.024^{\mathrm{a}}$ & $0.024^{\mathrm{a}}$ & $0.024^{\mathrm{a}}$ \\
PAH + no bacteria (control) & & & \\
\hline
\end{tabular}

Means in the same column with the same letter are not significantly different at $5 \%$ level of significance according to LSD test.

Table 3 shows result on the biodegradation of polycyclic aromatic hydrocarbons (PAHs) by a mixed culture of bacteria and fungi and in combination with NPK fertilizer and cow dung. In all the treatments and intervals, the control had an unchanged quantity of PAHs. There was high significant difference (ANOVA) in the quantity of PAHs remaining after each week. On the seventh day, PAHs + mixed 
culture of bacteria and fungi treatment had the least quantity of PAHs remaining. While PAHs + cow dung + mixed culture of bacteria and fungi treatment had the highest quantity of PAHs remaining. PAHs + cow dung + mixed culture of bacteria and fungi treatment had the least quantity of PAHs remaining on the fourteenth day. Both PAHs + mixed culture of bacteria and fungi, and PAHs + NPK fertilizer + mixed culture of bacteria and fungi treatments had similar highest quantity of PAHs remaining at day 14 . While at day 21, there was a total loss of PAHs in all the treatment systems.

Table 3. Biodegradation of polycyclic aromatic hydrocarbons (PAHs) by a mixed culture of bacteria and fungi and in combination with NPK fertilizer and cow dung.

\begin{tabular}{llll}
\hline TREATMENTS & 7 DAYS 14 DAYS 21 DAYS \\
\hline PAH + mixed culture of bacteria and fungi & & & \\
PAH + NPK + mixed culture of bacteria & $0.003^{\mathrm{c}}$ & $0.002^{\mathrm{b}}$ & $0.00^{\mathrm{b}}$ \\
and fungi & $0.007^{\mathrm{b}}$ & $0.002^{\mathrm{b}}$ & $0.00^{\mathrm{b}}$ \\
PAH + cow dung+ mixed culture of & $0.008^{\mathrm{b}}$ & $0.001^{\mathrm{c}}$ & $0.00^{\mathrm{b}}$ \\
bacteria and fungi & $0.024^{\mathrm{a}}$ & $0.024^{\mathrm{a}}$ & $0.024^{\mathrm{a}}$ \\
PAH + no microorganism(control) & & & \\
\hline
\end{tabular}

Means in the same column with the same letter are not significantly different at $5 \%$ level of significance according to LSD test.

Tables 4-6 show the effect of time on the biodegradation of polycyclic aromatic hydrocarbons (PAHs) by a mixed culture of bacteria and fungi in the different treatments. In all, it was observed that there were significant differences in the level of PAHs detected after analysis on weekly intervals. It was equally observed that the level of PAHs decreased as the period of exposure increased except the controls that had equal level of PAHs all through the exposure period ( 7 days to 21 days).

Table 4. Effect of time on the biodegradation of polycyclic aromatic hydrocarbons (PAHs) by mixed cultures of bacteria and fungi.

\begin{tabular}{llll}
\hline TREATMENTS & 7 DAYS & 14 DAYS & 21 DAYS \\
\hline PAH + bacteria & $0.022^{\mathrm{a}}$ & $0.001^{\mathrm{b}}$ & $0.00^{\mathrm{c}}$ \\
PAH + fungi & $0.021^{\mathrm{a}}$ & $0.014^{\mathrm{b}}$ & $0.00^{\mathrm{c}}$ \\
PAH + bacteria and fungi & $0.039^{\mathrm{a}}$ & $0.002^{\mathrm{b}}$ & $0.00^{\mathrm{b}}$ \\
PAH only (control) & $0.024^{\mathrm{a}}$ & $0.024^{\mathrm{a}}$ & $0.024^{\mathrm{a}}$ \\
\hline
\end{tabular}

Means in the same column with the same letter are not significantly different at $5 \%$ level of significance according to LSD test.

Table 5. Effect of time on the biodegradation of polycyclic aromatic hydrocarbons (PAHs) by mixed cultures of bacteria and fungi and in combination with cow dung.

\begin{tabular}{llll}
\hline TREATMENTS & 7 DAYS & 14 DAYS & 21 DAYS \\
\hline PAH + cow dung + bacteria & $0.001^{\mathrm{a}}$ & $0.007^{\mathrm{b}}$ & $0.00^{\mathrm{c}}$ \\
PAH + cow dung + fungi & $0.011^{\mathrm{a}}$ & $0.005^{\mathrm{b}}$ & $0.00^{\mathrm{c}}$ \\
PAH + cow dung + bacteria + fungi & $0.008^{\mathrm{a}}$ & $0.001^{\mathrm{b}}$ & $0.00^{\mathrm{b}}$ \\
PAH only (control) & $0.024^{\mathrm{a}}$ & $0.024^{\mathrm{a}}$ & $0.024^{\mathrm{a}}$ \\
\hline
\end{tabular}

Means in the same column with the same letter are not significantly different at $5 \%$ level of significance according to LSD test.
Table 6. Effect of time on the biodegradation of polycyclic aromatic hydrocarbons (PAHs) by mixed cultures of bacteria and fungi and in combination with NPK fertilizer.

\begin{tabular}{llll}
\hline TREATMENTS & 7 DAYS & 14 DAYS & 21 DAYS \\
\hline PAH + NPK + bacteria & $0.007^{\mathrm{a}}$ & $0.003^{\mathrm{b}}$ & $0.00^{\mathrm{c}}$ \\
PAH + NPK + fungi & $0.008^{\mathrm{a}}$ & $0.005^{\mathrm{b}}$ & $0.00^{\mathrm{c}}$ \\
PAH + NPK + bacteria + fungi & $0.007^{\mathrm{a}}$ & $0.002^{\mathrm{b}}$ & $0.00^{\mathrm{b}}$ \\
PAH only (control) & $0.024^{\mathrm{a}}$ & $0.024^{\mathrm{a}}$ & $0.024^{\mathrm{a}}$ \\
\hline
\end{tabular}

Means in the same column with the same letter are not significantly different at $5 \%$ level of significance according to LSD test.

Table 7 shows the results on the biodegradation of individual polycyclic aromatic hydrocarbons by a mixed culture of bacteria (Pseudomonas sp., Bacillus sp. and Klebsiella sp.) and fungi (Aspergillus sp., Penicillium sp., Saccharomyces sp. and Candida sp.) after 7 days, 14 days and 21 days. In the case of bacteria, result of the analysis after 7 days revealed the absence of naphthalene, acenaphthene, acenaphthylene, fluorene, phenanthrene, anthracene, indeno(1,2,3-C.D) pyrene and 1,2,5,6-dibenzanthracene. However, fluoranthene, pyrene, 1,2-benzanthracene, chrysene, benzo(b)fluoranthene, enzo(k)fluoranthene, benzo(a)pyrene and 1,12-benzoperylene had values that ranged between $0.0002 \mathrm{mg} / 1$ to $0.008 \mathrm{mg} / \mathrm{l}$. On the $14^{\text {th }}$ day, benzo(k)fluoranthene and benzo(a)pyrene had values of $0.0004 \mathrm{mg} / \mathrm{l}$ and $0.0005 \mathrm{mg} / \mathrm{l}$, respectively. Analysis after 21 days showed complete absence of all the polycyclic aromatic hydrocarbons (PAHs). In the case of fungi, on day seven, naphthalene, acenaphthalene, acenaphthylene and fluorene, were completely used by the degrading microorganisms. During this period, indeno(1,2,3-C.D)pyrene and 1,2,5,6-dibenzanthracene had the highest and lowest values, respectively. Further analysis on day 14, showed that benzo(a)pyrene had the least value of $0.0008 \mathrm{mg} / \mathrm{l}$, followed by 1,12-benzoperylene $(0.0004 \mathrm{mg} / \mathrm{l})$. Indeno(1,2,3C.D)pyrene and 1,2,5,6-dibenzanthracene had $0.002 \mathrm{mg} / 1$ each, while $0.005 \mathrm{mg} / \mathrm{l}$ was detected each for benzo(b)fluoranthene and benzo(k)fluoranthene. On the $21^{\text {st }}$ day, the PAHs were all degraded except indeno(1,2,3C.D)pyrene and 1,2,5,6-dibenzanthracene that each had value of $0.0009 \mathrm{mg} / \mathrm{l}$.

The effect of NPK fertilizer on the biodegradation of individual polycyclic aromatic hydrocarbon (PAH) by a mixed culture of bacteria (Pseudomonas sp., Bacillus sp.and Klebsiella sp.) presented in Fig. 1 shows the results for the 7 th day, 14 th day and 21 st day analysis. On the 7 th day, there was complete absence of phenanthrene, anthracene and fluoranthene. After 14 days, it was observed that most of the polycyclic aromatic hydrocarbons (PAHs) were absent except indeno (1, 2, 3-C.D) pyrene, 1,2,5,6dibenzanthracene and 1,12-benzoperylene that had values of $0.002 \mathrm{mg} / \mathrm{l}, 0.0013 \mathrm{mg} / \mathrm{l}$ and $0.0003 \mathrm{mg} / \mathrm{l}$, respectively remaining as against the $0.03 \mathrm{mg} / \mathrm{l}$ of each $\mathrm{PAH}$ initially used for the test. The result of the analysis after 21 days showed complete absence of all the PAHs used for the experiment. 
Table 7. Biodegradation of individual polycyclic aromatic hydrocarbon by a mixed culture of bacteria and Fungi.

\begin{tabular}{|c|c|c|c|c|c|c|}
\hline \multirow[t]{2}{*}{ PAHs } & \multicolumn{2}{|c|}{ 7days (mg/l) } & \multicolumn{2}{|c|}{ 14days (mg/l) } & \multicolumn{2}{|c|}{ 21days (mg/l) } \\
\hline & Bacteria & Fungi & Bacteria & Fungi & Bacteria & Fungi \\
\hline \multicolumn{7}{|l|}{ Naphthalene } \\
\hline \multicolumn{7}{|l|}{ Acenaphthene } \\
\hline \multicolumn{7}{|l|}{ Acenaphthylene } \\
\hline \multicolumn{7}{|l|}{ Fluorene } \\
\hline Phenanthrene & & 0.001 & & & & \\
\hline Anthracene & & 0.001 & & & & \\
\hline Fluoranthene & 0.0005 & 0.0 .02 & & & & \\
\hline Pyrene & 0.0034 & 0.0012 & & & & \\
\hline 1,2-Benzanthracene & 0.00024 & 0.002 & & & & \\
\hline Chrysene & 0.0002 & 0.002 & & & & \\
\hline Benzo(b)Fluoranthene & 0.008 & 0.0015 & & 0.005 & & \\
\hline Benzo(k)Fluoranthene & 0.004 & 0.002 & 0.0004 & 0.005 & & \\
\hline Benzo(a)Pyrene & 0.005 & 0.003 & 0.0005 & 0.0008 & & \\
\hline Indeno(1,2,3-C.D)Pyrene & & 0.005 & & 0.002 & & 0.0009 \\
\hline $1,2,5,6-$ & & 0.0003 & & 0.002 & & 0.0009 \\
\hline \multicolumn{7}{|l|}{ Dibenzanthracene } \\
\hline 1,12-Benzoperylene & 0.0004 & 0.0006 & & 0.0004 & & \\
\hline
\end{tabular}

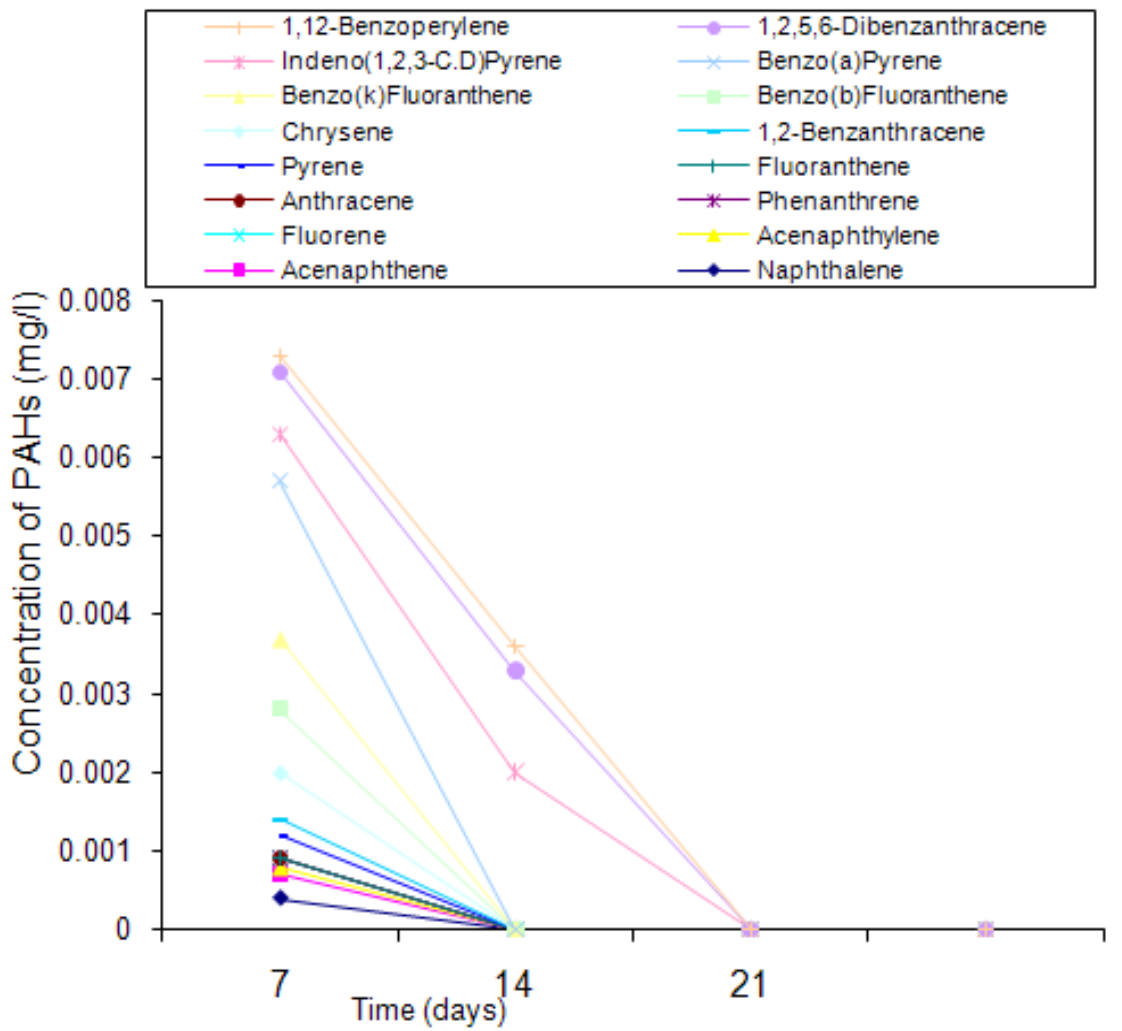

Fig.1. Effect of NPK fertilizer on the biodegradation of individual polycyclic aromatic hydrocarbon by a mixed culture of bacteria. 
The effect of cow dung on the biodegradation of individual polycyclic aromatic hydrocarbons (PAHs) by a mixed culture of bacteria (Pseudomonas sp., Bacillus sp. and Klebsiella sp.) presented in Fig. 2 revealed that after 7 days fluoranthene, pyrene, 1,2-benzanthracene, chrysene, benzo(b) fluoranthene, benzo(k)flouranthene, benzo (a) pyrene, indeno(1,2,3-C.D)pyrene, 1,2,5,6-dibenzanthracene and 1,12-benzoperylene had values that ranged between $0.0003 \mathrm{mg} / \mathrm{l}$ to $0.0022 \mathrm{mg} / \mathrm{l}$.

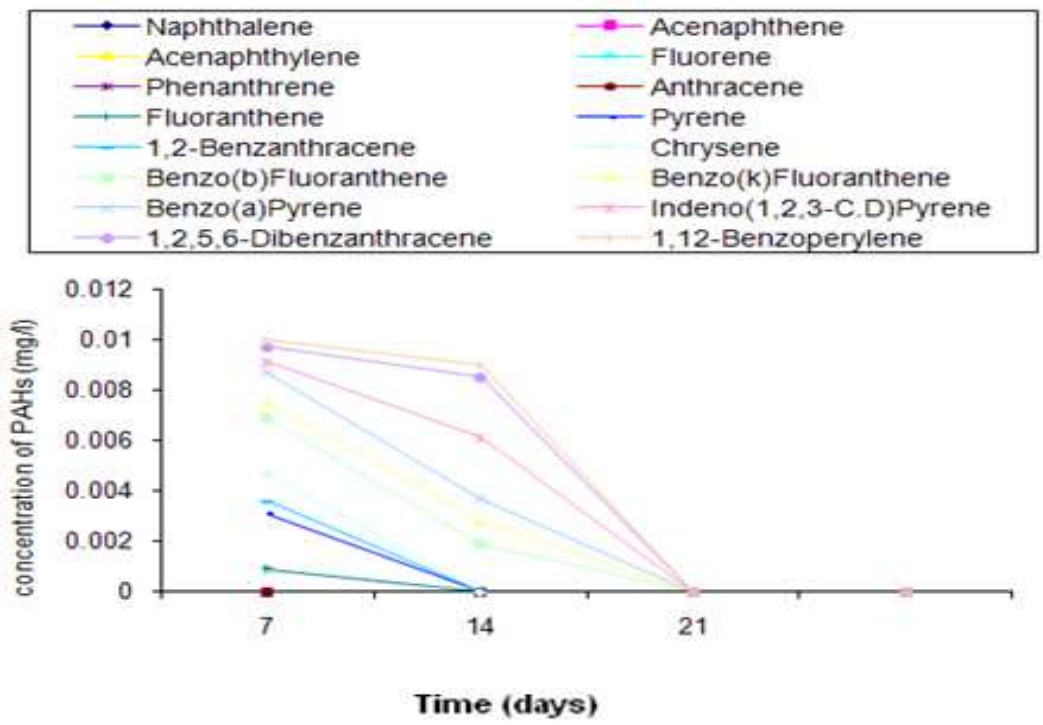

Fig.2. Effect of cow dung on the biodegradation of individual polycyclic aromatic hydrocarbon by a mixed culture of bacteria.

On the $14^{\text {th }}$ day, values that ranged between $0.0005 \mathrm{mg} / \mathrm{l}$ to $0.0024 \mathrm{mg} / \mathrm{l}$ were detected among benzo(b)fluoranthene, benzo(k)fluoranthene, benzo(a)pyrene, indeno(1,2,3C.D)pyrene, 1,2,5,6-dibenzanthracene and 1,12benzoperylene. However, there was absence of all the polycyclic aromatic hydrocarbons (PAHs) after 3 weeks (21 days).

Fig. 3 shows the effect of NPK fertilizer on the biode- gradation of individual polycyclic aromatic hydrocarbon (PAH) by a mixed culture of fungi (Aspergillus sp., Penicillium sp., Saccharomyces sp. and Candida sp.). Out of the sixteen PAH types analysed, four which include: naphthalene, acenaphthalene, acenaphthylene and fluorene were absent on day seven. Among those detected, benzo (a) pyrene and 1, 2-benzanthracene had the highest and lowest levels of $0.0013 \mathrm{mg} / 1$ and $0.0002 \mathrm{mg} / \mathrm{l}$, respectively.

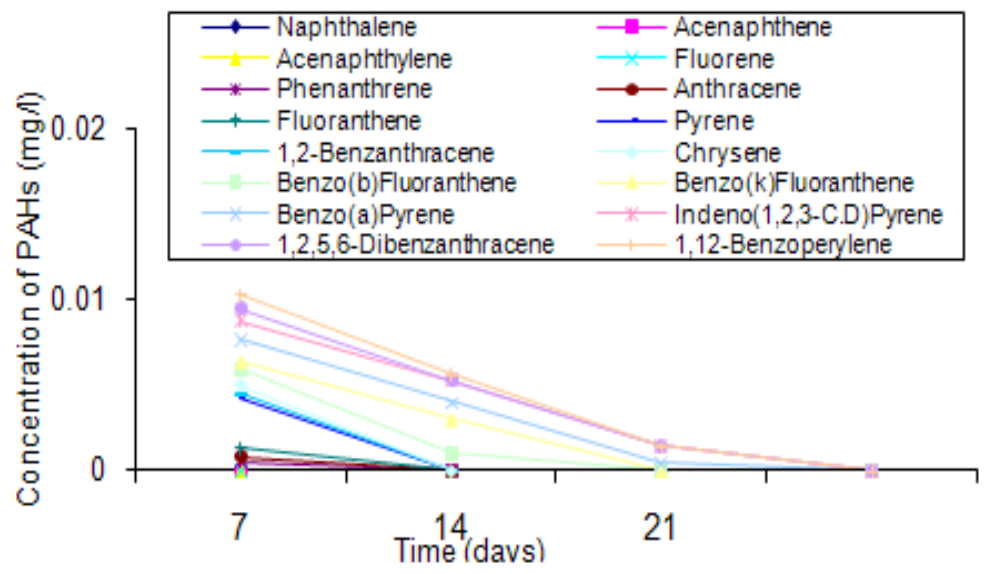

Fig.3. Effect of NPK fertilizer on the biodegradation of individual polycyclic aromatic hydrocarbon by a mixed culture of fungi.

On day 14, while benzo(a) pyrene had the highest level of $0.001 \mathrm{mg} / \mathrm{l}, 1,12$-benzoperylene had the least level of $0.0003 \mathrm{mg} / \mathrm{l}$. Benzo(b)fluoranthene, benzo(k)fluoranthene and indeno(1,2,3-C.D)pyrene had values of $0.001 \mathrm{mg} / \mathrm{l}$, $0.002 \mathrm{mg} / \mathrm{l}$ and $0.0013 \mathrm{mg} / \mathrm{l}$, respectively.

On day 21, benzo(a)pyrene, and indeno(1,2,3-
C.D)pyrene which were the only two detected had values of $0.0004 \mathrm{mg} / \mathrm{l}$ and $0.001 \mathrm{mg} / \mathrm{l}$, respectively.

The effect of cow dung on the biodegradation of individual polycyclic aromatic hydrocarbon (PAH) by a mixed culture of fungi (Aspergillus sp., Penicillium sp., Saccharomyces sp. and Candida sp.) are presented in Fig. 4 for 
days 7,14 and 21 analysis. From the results, there was complete degradation of naphthalene, acenaphthalene, acenaphthylene, fluorene and 1,2-benzanthracene on day 7. On day 14 , there was complete degradation of most PAHs except benzo(k)fluoranthene, benzo(a)pyrene, indeno(1,2,3C.D)pyrene, 1,2,5,6-dibenzanthracene and 1,12- benzoperylene that showed reduction from $0.03 \mathrm{mg} / \mathrm{l}$ used initially for the test to $0.003 \mathrm{mg} / 1,0.0003 \mathrm{mg} / \mathrm{l}, 0.0004$ $\mathrm{mg} / \mathrm{l}, 0.0003 \mathrm{mg} / \mathrm{l}$ and $0.002 \mathrm{mg} / \mathrm{l}$, respectively. Further analysis on day 21 revealed complete degradation of every PAH used except 1,12- benzoperylene that had value of $0.0003 \mathrm{mg} / \mathrm{l}$.

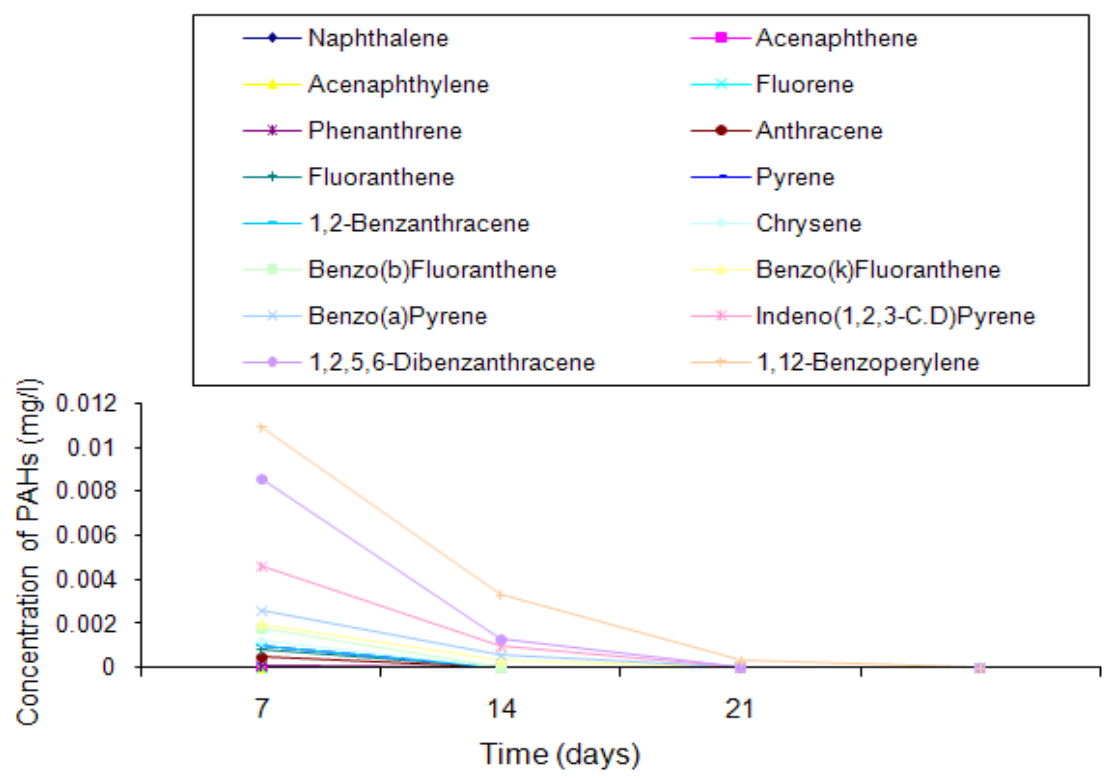

Fig.4. Effect of cow dung on the biodegradation of individual polycyclic aromatic hydrocarbon by a mixed culture of fungi.

The result of the effect of NPK fertilizer on the biodegradation of individual PAHs by a mixed culture of bacteria and fungi are shown graphically in Fig. 5. Benzo(b)fluoranthene, benzo(k)fluoranthene, benzo(a)pyrene, indeno(1,2,3-C.D)pyrene, 1,2,5,6-dibenzanthracene and 1,12-benzoperylene had values of $0.001 \mathrm{mg} / 1,0.002 \mathrm{mg} / \mathrm{l}$,
$0.0024 \mathrm{mg} / 1,0.0004 \mathrm{mg} / 1,0.0003 \mathrm{mg} / \mathrm{l}$ and $0.0004 \mathrm{mg} / \mathrm{l}$, respectively detected on the $7^{\text {th }}$ day. Likewise, benzo(b)fluoranthene, benzo(k)fluoranthene and benzo(a)pyrene had values of $0.001 \mathrm{mg} / 1,0.0004 \mathrm{mg} / \mathrm{l}$ and $0.0009 \mathrm{mg} / \mathrm{l}$, respectively detected on day 14 . Analysis on the $21^{\text {st }}$ day revealed total loss of all the PAHs.

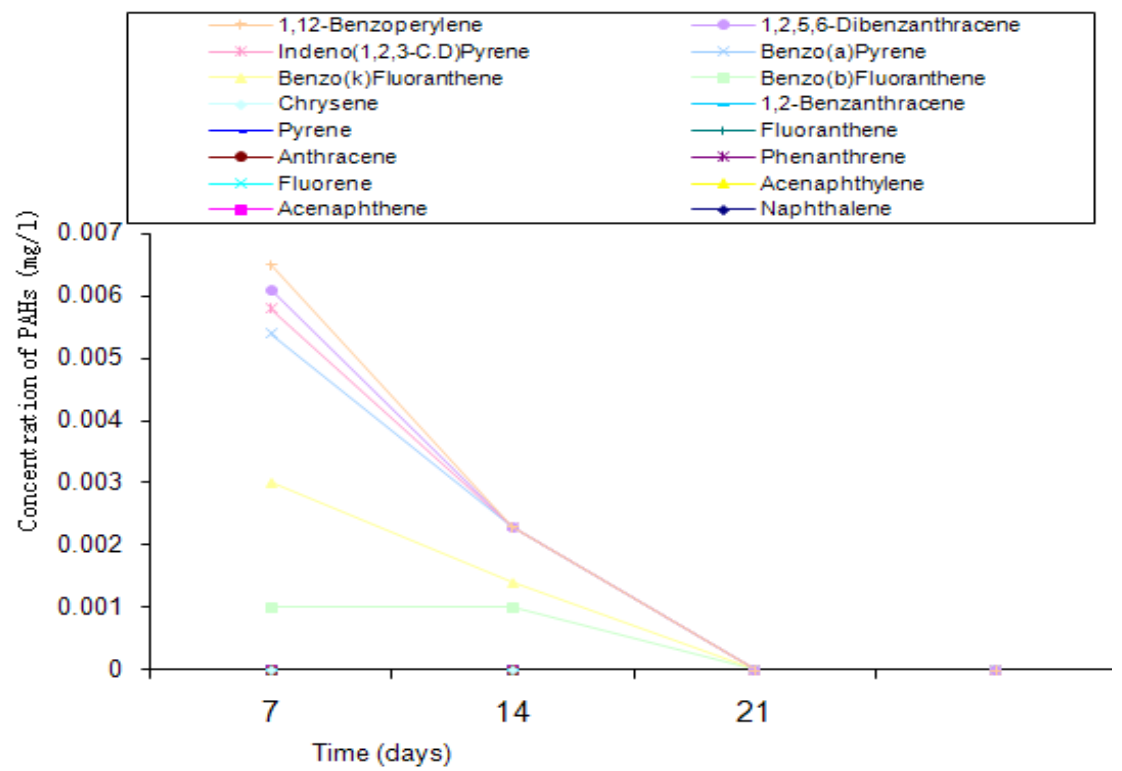

Fig. 5. Effect of NPK fertilizer on the biodegradation of individual polycyclic aromatic hydrocarbon by a mixed culture of bacteria and fungi.

The effect of cow dung on the biodegradation of individual polycyclic aromatic hydrocarbon (PAH) by a mixed culture of bacteria (Pseudomonas sp., Bacillus sp. and
Klebsiella sp.) and fungi (Aspergillus sp. Penicillium sp., Saccharomyces sp. and Candida sp.) presented graphically in Fig. 6 indicates that PAH level ranging from $0.0002 \mathrm{mg} / \mathrm{l}$ 
to $0.004 \mathrm{mg} / \mathrm{l}$ was detected for benzo(a)pyrene, indeno(1,2,3-C.D)pyrene,1,2,5,6-dibenzanthracene and 1,12benzoperylene on day 7 . On day 14 , benzo(a)pyrene and indeno(1,2,3-C.D)pyrene had $0.0004 \mathrm{mg} / 1$ and $0.001 \mathrm{mg} / \mathrm{l}$, respectively detected, while on day 21 , no PAH was detected, indicating complete and total degradation of all the PAHs in the treatment systems.

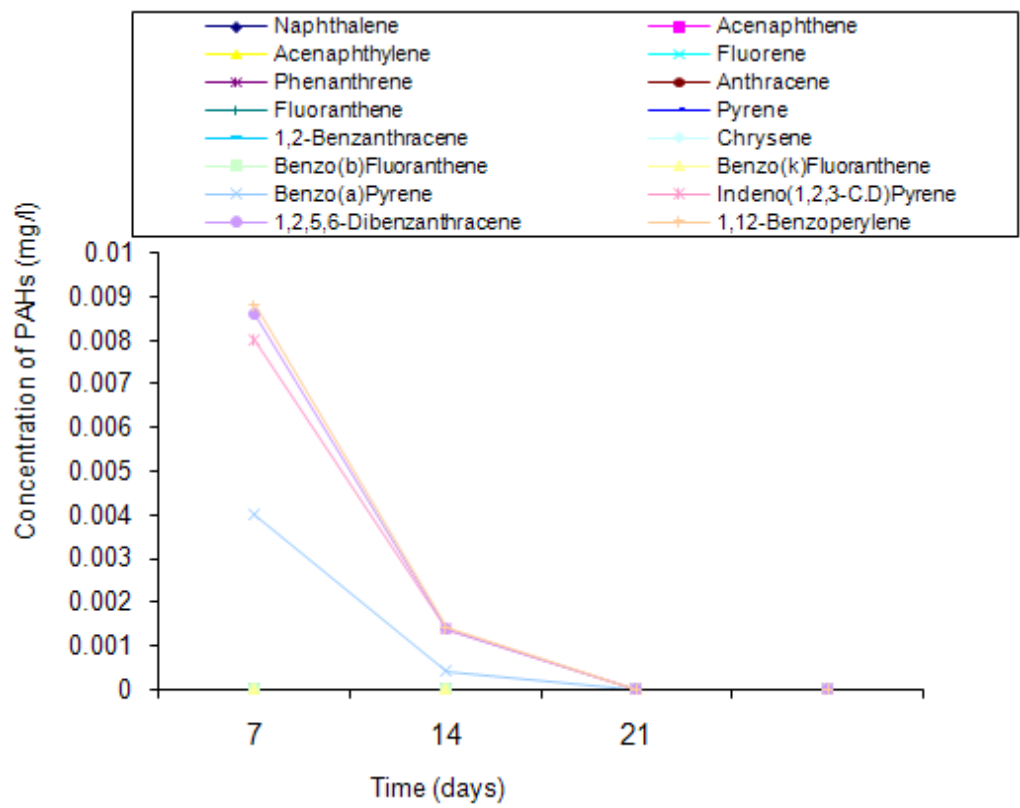

Fig.6. Effect of cow dung on the biodegradation of individual polycyclic aromatic hydrocarbon by a mixed culture of bacteria and fungi.

The overall biodegradation results for days 7, 14 and 21 are shown graphically in Fig. 7. From the result, naphthalene, acenaphthalene, acenaphthylene, fluorene, 1,2,5,6dibenzanthracene and 1,2-benzoperylene only were completely degraded. Analysis on the $14^{\text {th }}$ day indicates that all the PAHs except benzo(b)fluoranthene, benzo(k)fluoranthene, benzo(a)pyrene and indeno(1,2,3C.D)pyrene were detected, while on the $21^{\text {st }}$ day $1,12-$ benzoperylene only was detected while others were completely degraded.

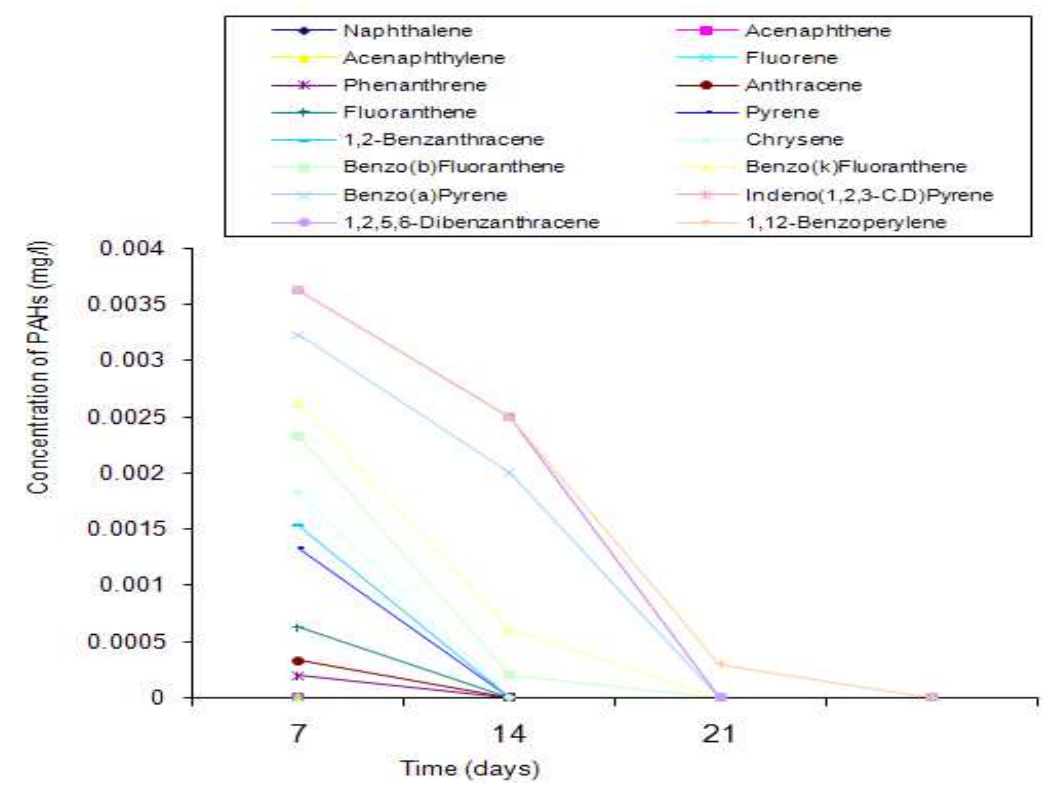

Fig.7. Biodegradation of individual polycyclic aromatic hydrocarbon by a mixed culture of bacteria and fungi.

\section{Discussion}

Mixed cultures of bacteria (Pseudomonas sp., Bacillus sp. and Klebsiella sp.) and fungi (Aspergillus sp., Penicil- lium sp., Saccharomyces sp. and Candida sp.) were used for the biodegradation test. Although some PAHs are toxic, carcinogenic and teratogenic,[45] reported that a variety of bacteria can degrade certain PAHs completely to $\mathrm{CO}_{2}$ and metabolic intermediates, en route gaining energy and car- 
bon for cell growth.

The biodegradation tests results showed slight drop in the initial concentration of the polycyclic aromatic hydrocarbons (PAHs) used as control. This could be as a result of the failure of the extractant to extract all the PAHs added. The treatment (PAHs + mixed culture of bacteria) had the least quantity of PAHs remaining; this could be as a result of the failure of the extractant to extract all the PAHs added to the treatment. Lowest concentration of PAHs detected on day 7 (Table 3 ) for PAHs + mixed culture of bacteria and fungi treatment could be as a result of experimental error. Tables 4-6 indicated that with the exception of the control, the concentrations of polycyclic aromatic hydrocarbons (PAHs) decreased with increase in exposure time. This implies that the concentration of PAHs used in the study was not toxic to the degrading microorganisms. Based on this, the organisms constantly utilized the substrate (PAHs) throughout the duration of the experiment.

The observations in Table 7 indicate that in most cases, low molecular weight PAHs were absent indicating degradation. This observation corroborates the report by[46] that there is preferential attack on less complex aromatic molecules. Also[29] reported those PAHs with 2 or 3 rings e.g. naphthalene, anthracenes are more biodegradable. The high molecular weight polycyclic aromatic hydrocarbons were observed not to be easily degraded in most cases after the $7^{\text {th }}$ day and $14^{\text {th }}$ day except on the $21^{\text {st }}$ day. This is because the environmental fate of a polycyclic aromatic hydrocarbon (PAH) particle is dependent in part on both its molecular size i.e. the number of aromatic rings and patterns of ring linkages[16]. Also[16] reported that increase in the size and angularity of a PAH molecule results in a concomitant increase in hydrophobicity and electrochemical stability. The observation was further supported by a report[29] that PAH molecule stability and hydrophobicity are two primary factors that contribute to the persistence of high molecular weight PAHs in the environment.

However, comparing the degradation efficiency of bacteria and fungi mixed cultures on polycyclic aromatic hydrocarbons (PAHs), it is evident from this study that no definite pattern was established. This then indicates that both bacteria and fungi isolates used for the study possess similar enzymatic capability to degrade polycyclic aromatic hydrocarbons (PAHs). The trend observed in this study is in contrast with that of[44] who observed that fungi have a greater capacity and enzymatic capability to degrade polycyclic aromatic hydrocarbons (PAHs) than bacteria. However, some researchers e.g.[13],[47],[48],[49] have all reported that fungi are good PAH degraders while[50],[51],[52],[53] have reported that bacteria are good degraders of polycyclic aromatic hydrocarbons (PAHs). It was reported by[54] that addition of organic material accelerated the removal of PAHs and that addition of low dose of cattle manure removed $42.3 \%$ of PAHs while medium and high doses removed $26.1 \%$ and $25.5 \%$ of PAHs respectively.

The treatment with mixed cultures of microorganisms is better than single treatment where only bacteria or fungi species are used singly. However bacteria are more efficient biodegraders than fungi. Cow dung has greater potential for biodegradation than NPK. Cow dung contributes diverse species of microorganisms which further enhances natural biogeochemical processes[55],[56]. Both NPK and Cow dung have the capacity to completely degrade most PAHs within 21 days except benzo (a) pyrene benzoperylene and indeno $(1,2,3,-$ C.D) pyrene.

\section{Conclusion}

The study showed that treatment with mixed cultures of microorganisms is better than single treatment where only bacteria or fungi species are used singly. Also bacteria are more efficient biodegraders than fungi and Cow dung has greater potential for biodegradation than NPK. The study also indicated negative impact of abattoir activities on the soil and also demonstrated that organic waste amendments significantly decreased soil PAHs.

Although abattoir operation could be very beneficial to man because it provides meat for human consumption and other useful by-products, still it can be very hazardous to public health with respect to the wastes that is generated. The high pollution strength of the abattoir wastes as revealed in this study further confirmed the danger associated with discharging untreated wastes to the environment, thus the need for adequate treatment to ensure decontamination.

Based on the foregoing, the abattoir management system should include a waste management plan designed for abattoir operations. Legislative measures are also necessary, laws and rules on land use and waste regulation to control the location and management of abattoirs should be made.

\section{References}

[1] Hughes, J B., Beckles, D M., Chandra, S D., Ward, C H. Utilization of bioremediation for the treatment of PAHcontaminated sediments. J. Ind. Microbiol. Biotech. 1997, 18: $152-160$.

[2] Okafor, E. Ch., Opuene, K. Preliminary assessment of trace metals and polycyclic aromatic hydrocarbons in the sediments. Int. J Environ Sci Tech 2007, 4(2): 233-240.

[3] Fagbote, E O., Olanipekun, E O. Levels of polycyclic aromatic hydrocarbons and polychlorinated biphenyls in sediment of bitumen deposit impacted area. Int. J Environ Sci Tech 2010, 7(3): 561-570.

[4] Lee, K H., Byeon, S H. The biological monitoring of urinary 1 hydroxypyrene by PAH exposure among smokers. Int. J Environ Res. 2010, 4(3):439-442.

[5] Keith L H, Telliard W A,. Priority pollutants I. A perspective view. Environmental Science and Technology, 1979, 13(4):416-423.

[6] Eibes G, Cajthaml T, Moreira M T, Feijoo G, Lema J M, Enzymatic degradation of anthracene, dibenzothiophene and pyrene by manganese peroxidase in media containing ace- 
tone. Chemosphere, 2006, 64(3): 408-414.

[7] Ockenden W A, Breivik K, Meijer S N, Steinnes E, Sweetman AJ, Jones K C,. The global re-cycling of persistent organicpollutants is strongly retarded by soils. EnvironmentalPollution, 2003, 121(1): 75-80.

[8] Mohan S V, Kisa T, Ohkuma T, Kanaly R A, ShimizuY, Bioremediation technologies for treatment ofPAHcontaminated soil and strategies to enhance process efficiency. Reviews in Environmental Science and Biotechnology, 2006, 5(4): 347-374.

[9] Yu H, Huang G H, An C J, Wei J,. Combined effects of DOM extracted from site soil/compost and biosurfactant onthe sorption and desorption of PAHs in a soil-water system.Journal of Hazardous Materials, 2011, 190(1-3): 883890

[10] Osuji, L C ., Ezebuiro, P E. Hydrocarbon contamination of a typical mangrove floor in Niger Delta, Nigeria. Int. J Environ Sci Tech. 2006, 3(3): 313-320.

[11] Perugini, M., Visciano, P., Giammarino, A., Manera, M., Nardo, W D., Amorena, M. Polycyclic aromatic hydrocarbons in marine organisms from the Adriatic Sea Italy. Chemosphere 2007, 66(10): 1904-1910.

[12] Wilson, S C and Jones, K C,. Bioremediation of soil contaminated with polynuclear aromatic hydrocarbons (PAHs). A Review. Environ. Pollut. 1993, 81: 229-249.

[13] Cerniglia, C. E, Biodegradation of polycyclic aromatic hydrocarbons. Curr. Opin. Biotech., 1993, 3 (2-3), 331-338

[14] McElroy, A.E., Farrington, J W., Teal, J M. Degradation of PAHs by microorganisms. Appl. Environ. Microbiol. 1989, 55: 269-274.

[15] Cho, J.C, Kim, S J. Biodegradation of phenanthrene in soil microcosms. In: Int. In-situ and On-site Bioremediation Symp. New Orleans. 1997, Pp. 105-110.

[16] Harms, H., Bosman, T.N.P.. Mass transfer limitation of microbial growth and pollutant degradation. J. Indust. Microbiol. Biotech. 1997, 18: 97-105.

[17] Debosz K, Petersen S O, Kure L K, Ambus P,. Evaluating effects of sewage sludge and household compost on soil physical, chemical and microbiological properties. Applied Soil Ecology, 2002, 19(3): 237-248.

[18] Celik I, Ortas I, Kilic S,. Effects of compost, mycorrhiza, manure and fertilizer on some physical properties of a Chromoxerert soil. Soil \& Tillage Research, 2004, 78(1): 59-67.

[19] Courtney R G, Mullen G J,. Soil quality and barley growth as influenced by the land application of two compost types. Bioresource Technology, 2008, 99(8): 2913-2918.

[20] Alvarez-Bernal D, Garc'ia-D'iaz E L, Contreras-Ramos S M,Dendooven L,. Dissipation of polycyclic aromatic hydrocarbonsfrom soil added with manure or vermicompost.Chemosphere, 2006, 65(9): 1642-1651.

[21] Contreras-Ramos S M, Alvarez-Bernal D, Dendooven L, Removal of polycyclic aromatic hydrocarbons from soilamended with biosolid or vermicompost in the presence of earthworms (Eisenia fetida). Soil Biology and Biochemistry, 2008, 40(7): 1954-1959.
[22] Fernan dez-Luqueno, F., Marsch, R., Espinosa-Victoria. D., Thalasso, F., Lara, M E H. Remediation of PAHs in a salinealkaline soil amended with wastewater sludge and the effect on dynamics of C and N. Science of the Total Environment. 2008, 402 (1): 18-28.

[23] Simeon N, Mercier G, Blais J F, Ouvrard S, Sauvage C, RenatJ C,. Decontamination of contaminated soilsby polycyclic aromatic hydrocarbons in the presence ofsupplementary organic structures. Journal of Environmental Engineering and Science, 2008, 7: 467-479.

[24] Kobayashi T, Navarro R R, Tatsumi K, Iimura Y,. Influenceof compost amendment on pyrene availability fromartificially spiked soil to two subspecies of Cucurbita pepo. Science of the Total Environment, 2008, 404(1): 1-9.

[25] ejada M, Masciandaro G,. Application of organic wasteson a benzo(a)pyrene polluted soil. Response of soilbiochemical properties and role of Eisenia fetida. Ecotoxicologyand Environmental Safety, 2011, 74(4): 668-674.

[26] Bouchez, M., Blanchet, D. ,Vandecas-Teele, J.P. Degradation of polycyclic aromatic hydrocarbons by pure strain and by defined strain association: Inhibition phenomena and cometabolism. Appl. Microbiol. Biotechnol. 1995, 43: 156164.

[27] Foght, J.M., Gutnick, D.L., Westlake, D.W.S. Effect of emulsion on biodegradation of crude oil in pure and mixed cultures. Appl. Environ. Microbiol. 1989, 55: 36-42.

[28] Mueller, J.G., Chapman, P.J., Pritchard, P.H. Action of a fluoranthene-utilizing bacterial community on polycyclic aromatic hydrocarbon components of creosote. Appl. Environ. Microbiol. 1989, 55: 1504-1506.

[29] Park, K.S., Sims, R.C., Dupont, R. The fate of the PAH compounds in two soil types: Influence of volatalization of abiotic loss and biological activity. Environ. Toxicol. Chem. 1990, 9(2): 187-196.

[30] Miyachi, N., Tanaka, T., Suzuki, T., Hotta, Y., Omori, T. Microbial oxidation of dimethylnaphthalene isomers. Appl. Environ.Microbiol. 1993, 59: 1938-1942.

[31] Sanseverino, J., Applegate, B.M., King, J.M.H., Sayler, G S. Plasmid-mediated mineralization of naphthalene, phenanthrene and anthracene. Appl. Environ. Microbiol. 1993, 59: 1931-1937.

[32] [32]. Menn, F.M., Applegate, B.M., Soyler, G.S.. NAH catabolism of anthracene and phenanthrene to naphtholic acids. Appl. Environ. Microbiol. 1993, 59: 1938-1942.

[33] Denome, S.A., Stanley, D.C., Olson, E.S., Young K.D. Metabolism of dibenzothiophene and naphthalene in Pseudomonas strains: complete DNA sequence of the upper naphthalene catabolic pathway. J. Bacteriol. 1994, 175: 68906901.

[34] Leahy, G.J. and Colwell, R.R. Microbial degradation of hydrocarbon in the environment. Microbiol. Rev. 1990, 54(3): 303-315.

[35] Dibble, J.T., Bartha, R. Effect of environmental parameters on the biodegradation of oil sludge. Appl. Environ. Microbiol. 1985, 37: 729-739.

[36] Odokuma, L.O., Okpokwasili, G.C. Seasonal influences on inorganic anion monitoring of the New Calabar River, Nige- 
ria. Environ. Manage. 1993, 17(4): 491-496.

[37] Onyeagba, R.A., Umeham, S.N. Analytical Methods in Water Microbiology. In: Onyeagba, R.A. (ed.). Laboratory Guide for Microbiology. $1^{\text {st }}$ ed. Crystal Publishers Okigwe, Nigeria. 2004, Pp. 178-191.

[38] Adesemoye, A.O., Opere, B.O. and Makinde, S.C.O. Microbial content of abattoir waste water and its contaminated soil in Lagos, Nigeria. Afr. J. Biotechnol. 5(20): (2006), 1963-1968.

[39] Prescott, L.M., Harley, J.P., Klein, D.A. Microbiology. $6^{\text {th }}$ ed. McGraw Hill, London. 2005, Pp. 135-140.

[40] Holt, JG; Kreig, N; Sneath, P A H., Williams, S T. Bergey's Manual of Determinatve Bacteriology. $9^{\text {th }}$ edition. Williams and Wilkins Co., Baltimore, USA. 1994.

[41] Barnett, H L., Hunter, B B. Illustrated Genera of Imperfect Fungi. $3^{\text {rd }}$ ed. Burgess publishing company, Minnesota, USA. 1972

[42] Wang, W. Response of Nitrobacter sp. to toxicity. Environ. Int. 1984, $10: 21-26$.

[43] Okerentugba, P O., Ezeronye, O U. Petroleum-degrading potentials of single and mixed microbial cultures isolated from rivers and refinery effluents in Nigeria. Afr. J. Biotechnol. 2003, 2(9): 288-292.

[44] Okoro, C C. Biodegradation of hydrocarbons in untreated produce water using pure fungal cultures. Afr. J. Microbiol. Res. 2008, 2: 217-223.

[45] Hedlund, B P., Geiselbrecht, A D., Bair, T J, Staley, J T. Polycyclic aromatic hydrocarbons degradation by a new marine bacterium, Neptunomonas sp. Appl. Environ. Microbiol. 1999, 65(1): 251-259.

[46] Rothermich,M M., Hayes, L A., Lovley, D R. Anaerobic, sulphate-dependent degradation of polycyclic aromatic hydrocarbons in petroleum-contaminated habour sediment. Environ. Sci. Technol. 2002, 36: 4811-4817.
[47] Andrea, R C., Tania, A.A., Lucia, R D.. Biodegradation of polycyclic aromatic hydrocarbons by soil fungi. Braz. J. Microbiol. 2001, 32(4) : 124-129.

[48] Gadd, G M. Fungi in Bioremediation. Cambridge University Press, Cambridge. 2001, P. 220

[49] Sutherland, J B. Degradation of hydrocarbons by yeast and filamentous fungi. Fungial Biotechnology in Agricultural Food and Environmental Application. Arora, D.K(ed). Marcel Dekker Inc., USA. 2004, P. 324.

[50] [Haritash, A K., Kalushik, C P. Biodegradation aspects of polycyclic aromatic hydrocarbons (PAHs): A review. $\mathrm{J}$. $\mathrm{Ha}$ zard. Mat. 2009., 169: 1-15

[51] Hamamura, N., Olson, S H., Ward, D M., Inskeep, W P. Microbial population dynamics associated with crude oil biodegradation in diver2001se soil. Appl. Environ. Microbiol. 2006, 72(9): 6316-6324.

[52] Foght, J M., Westlake, D W S. Degradation of polycyclic aromatic hydrocarbons (PAHs) and aromatic heterocycles by a Pseudomonas sp. Can. J. Microbiol. 1988, 34: 11351141

[53] Okpokwasili, G C., Sommerville, C C., Sullivan, M., Grimes, D J., Colwell, R R. Plasmid-mediated degradation of hydrocarbons in estuarine bacteria. Oil Chem. Pollut. 1986, 3:177-129.

[54] Jing Z., Xiangui L., Weiwei L., Yiming W., Jun Z., Hong C. Effect of organic wastes on the plant-microbe remediation for removal of aged PAHs in soils. Journal Environ Sciences 2012, 24(8): 1476-1482.

[55] Adegunloye, D V., Adetuyi, F C., Akinyosoye, F A., Doyeni, M O. Microbial analysis of compost using cow dung as booster. Pak J Nutr 6(5): 2007, 506-510.

[56] Akinde, S B ., Obire, O. Aerobic heterotrophic bacteria and petroleum- utilizing bacteria from cow dung and poultry Imanure. World J Microbiol Biotechnol 2008, 24: 19992002. 